\title{
Komposit ZnO-CuO Hasil Sintesis dengan Metode Elektrokimia sebagai Katalis Fotodegradasi Methyl Orange
}

\author{
Adrian Nur ${ }^{1, a, *}$, Anis Yuliana Kusumaningrum ${ }^{1}$, Danang Bayu Prananda ${ }^{2}$ dan Tutut Ayu \\ Kinasih $^{2}$ \\ ${ }^{1}$ Program Studi Sarjana Teknik Kimia Fakultas Teknik Universitas Sebelas Maret \\ ${ }^{2}$ Program Studi Diploma III Teknik Kimia Sekolah Vokasi Universitas Sebelas Maret \\ E-mail: aadriannur@staff.uns.ac.id (*Corresponding author)
}

\begin{abstract}
Abstrak. Metal oxide semiconductors are one type of nanocomposites used for microelectronic circuits, piezoelectric devices, fuel cells, sensors, catalysts, surface coatings to prevent corrosion, and solar cells. $\mathrm{ZnO}$ $\mathrm{CuO}$ is a type of metal oxide semiconductor composite. The combination of these two metals can produce a composite that can be used for catalysts and antibacterial substances. Photodegradation method is a textile dyestuff treatment which breaks down organic dyes into simpler compounds. The purpose of this paper is to determine the effectiveness of $\mathrm{ZnO}-\mathrm{CuO}$ composites used as catalysts in the methyl orange photodegradation process. The method used in the synthesis of $\mathrm{ZnO}-\mathrm{CuO}$ composites is an electrochemical method using an acetic acid electrolyte solution. In this study, acetic acid was used with the concentration of 0.15 and $0.3 \mathrm{M}$. The resulting composites were analyzed using XRF, XRD and FTIR analysis. The composites are used as methyl orange photodegradation catalysts with different time variations 0 to 150 minutes. The absorbance of the degradation solution was measured by UV VIS Spectrophotometer. The effectiveness produced from the composites with concentrations of $0.3 \mathrm{M}$ acetic acid was $21.69 \%$, while the effectiveness produced from the composites with concentrations of $0.15 \mathrm{M}$ was $16.58 \%$. Catalysts produced at concentrations of $0.3 \mathrm{M}$ acetic acid are more effective than catalysts produced at concentrations of $0.15 \mathrm{M}$ acetic acid.
\end{abstract}

Kata kunci:. electrosynthesis, $\mathrm{ZnO}-\mathrm{CuO}$ composite, photodegradation, methyl orange, textile dyes

EQUILIBRIUM Volume 3 No.2 December 2019

Online at http:/ / equilibrium.ft.uns.ac.id 


\section{Pendahuluan}

Perkembangan industri tekstil di Indonesia dapat meningkatkan pencemaran lingkungan yang disebabkan oleh limbah zat warna. Salah satu contoh limbah zat warna yang banyak digunakan adalah metbyl orange. Metode fotodegradasi merupakan salah satu pengolahan limbah zat warna tekstil. Metode ini menguraikan zat warna organik kompleks menjadi senyawa yang lebih sederhana dengan bantuan cahaya (foton). Reaksi ini dapat dipercepat dengan menggunakan katalis [1]. Bahan semi konduktor banyak digunakan sebagai katalis proses fotodegradasi, salah satunya yaitu $\mathrm{ZnO}$ yang memiliki celah pita (band gap) sebesar 3,2-3,5 eV (elektron volt). Band gap tersebut cukup tinggi sehingga diperlukan paduan material yang dapat menurunkan nilai band gap tersebut. Paduan material $\mathrm{ZnO}$ dan $\mathrm{CuO}$ yang menghasilkan komposit semikonduktor oksida logam dapat digunakan sebagai katalis dan zat anti bakteri [2]. Komposit $\mathrm{ZnO}-\mathrm{CuO}$ yang dihasilkan melalui proses sintesis elektrokimia memiliki band gap yang lebih rendah sehingga memperbaiki pada sifat fotokatalitik $\mathrm{ZnO}$ [3]. Komposit $\mathrm{Cu}-\mathrm{ZnO}$ dengan $\mathrm{Al}_{2} \mathrm{O}_{3}$ banyak digunakan sebagai katalis untuk sintesis etanol dan metonol dari syngas [4, 5]. CuO-ZnO dapat digunakan juga sebagai sensor bahan organik [6]. Komposit $\mathrm{CuO}-\mathrm{ZnO}$ yang disintesis dengan metode sol gel telah digunakan sebagai anti bakteri [7]. Penelitian lain menggunakan $\mathrm{CuO}-$ $\mathrm{ZnO}$ sebagai katalis solar cell [8]. Belum ada penelitian yang membahas sintesis komposit $\mathrm{CuO}-\mathrm{ZnO}$ dengan metode elektrokimia dan mengaplikasikannya sebagai katalis fotodegradasi. Tujuan makalah ini adalah mengetahui efektivitas komposit $\mathrm{ZnO}-\mathrm{CuO}$ yang digunakan sebagai katalis pada proses fotodegradasi metbyl orange.

\section{Percobaan}

\subsection{Sintesis katalis komposit $\mathrm{ZnO}-\mathrm{CuO}$}

Sintesis katalis yaitu komposit $\mathrm{ZnO}-\mathrm{CuO}$ dilakukan dengan metode elektrokimia. Sebagai sumber $\mathrm{ZnO}$ dan $\mathrm{CuO}$ adalah plat $\mathrm{Zn}$ dan $\mathrm{Cu}$ ukuran $5 \times 2 \mathrm{~cm}$. Plat $\mathrm{Cu}$ sebagai anoda ditempatkan di antara dua plat $\mathrm{Zn}$ sebagai anoda dan katoda (Gambar 1). Larutan elektrolit yang digunakan terdiri dari asam asetat 0,15 dan $0,3 \mathrm{M}$ sebanyak $250 \mathrm{~mL}$ yang dinetralkan dengan $\mathrm{NaOH} 1 \mathrm{M}$. Proses elektrolisis berlangsung selama 2 jam pada tegangan $17 \mathrm{~V}$. Endapan yang dihasilkan selanjutnya dipisahkan dari larutan elektrolit tersisa dengan kertas saring. Partikel tersebut selanjutnya dikeringkan dalam oven suhu $80^{\circ} \mathrm{C}$ selama 20 jam. Partikel kemudian dikalsinasi dalam furnace pada suhu $300^{\circ} \mathrm{C}$ selama 5 jam. Partikel diuji dengan XRF, XRD, dan FTIR.

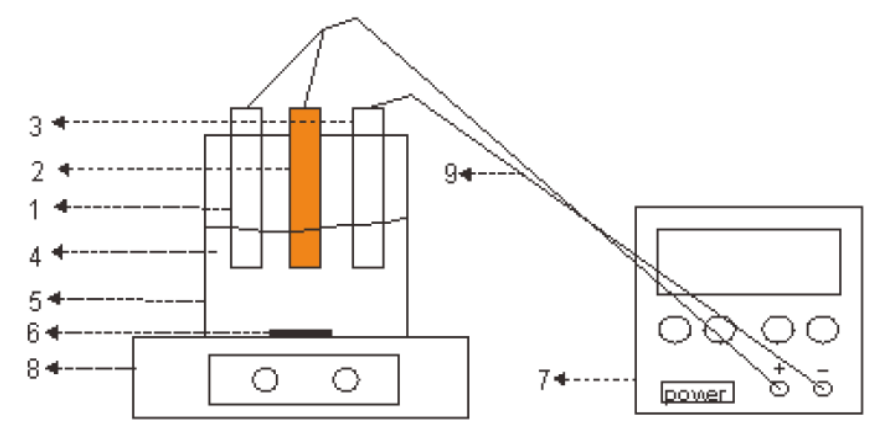
1. Plat Zn (anoda)
6. Pengaduk magnetik
2. Plat Cu (anoda)
7. Catu daya
3. Plat Zn (katoda)
8. Pemanas
4. Larutan elektrolit
9. Kabel penghubung
5. Beaker glass

Gambar 1. Rangkaian alat sintesis komposit $\mathrm{ZnO}-\mathrm{CuO}$ dengan metode elektrokimia

\subsection{Pengujian katalis komposit $\mathrm{ZnO}-\mathrm{CuO}$ pada fotodegradasi methyl orange}

Pengujian katalis komposit $\mathrm{ZnO}-\mathrm{CuO}$ dilakukan pada larutan methyl orange 8 ppm $25 \mathrm{~mL}$ dengan menambahkan katalis $0.065 \mathrm{~g}$. Campuran di-shaking $60 \mathrm{rpm}$. Absorbansi larutan methyl orange diukur dengan spektrofotometri UV-vis pada waktu 0, 30, 90, 120, dan 150 menit. Hasil pengukuran absorbansi larutan 
methyl orange dikonversi menjadi konsentrasi methyl orange dengan kurva kalibrasi yang telah dibuat sebelumnya yang menghubungkan konsentrasi methyl orange dengan absorbansinya.

\section{Hasil dan Pembahasan}

Prose pembuatan komposit $\mathrm{ZnO}-\mathrm{CuO}$ dilakukan dengan metode elektrokimia pada suasana netral dengan menggunakan power supply sebagai sumber listrik. Ketika power supply dinyalakan, terjadi reaksi oksida terhadap $\mathrm{Zn}$ dan $\mathrm{Cu}$ di plat anoda dengan melepaskan elektron untuk membentuk ion $\mathrm{Zn}^{2+}$ dan ion $\mathrm{Cu}^{2+}$.

$\mathrm{ZnO}-\mathrm{CuO}$ yang disintesis dari plat $\mathrm{Zn}$ dan $\mathrm{Cu}$ menggunakan metode elektrokimia mengikuti reaksi berikut : di anoda:

$$
\begin{aligned}
& \mathrm{Zn} \rightarrow \mathrm{Zn}^{+2}+2 \mathrm{e}^{-} \\
& \mathrm{Cu} \rightarrow \mathrm{Cu}^{+2}+2 \mathrm{e}^{-}
\end{aligned}
$$

di katoda :

$$
2 \mathrm{H}_{2} \mathrm{O}+2 \mathrm{e}^{-} \rightarrow \mathrm{H}_{2}+2 \mathrm{OH}^{-}
$$

Diagram spesiasi dari $\mathrm{Zn}$ dan $\mathrm{Cu}$ [4] memberikan gambaran bahwa pada $\mathrm{pH} 7, \mathrm{Zn}$ berubah menjadi $\mathrm{Zn}^{2+}$ dan ion $\mathrm{Zn}(\mathrm{OH})^{+}$, sementara $\mathrm{Cu}$ berubah menjadi $\mathrm{Cu}^{2+}$ dan ion $\mathrm{Cu}(\mathrm{OH})^{+}$. $\mathrm{ZnO}-\mathrm{CuO}$ terbentuk karena reaksi oksidasi [10] berikut ini :

$\mathrm{Zn}(\mathrm{OH})^{+} \rightarrow \mathrm{ZnO} \downarrow+\mathrm{H}^{+}+\mathrm{e}^{-}$

$\mathrm{Cu}(\mathrm{OH})^{+} \rightarrow \mathrm{CuO} \downarrow+\mathrm{H}^{+}+\mathrm{e}^{-}$

\subsection{Karakterisasi partikel komposit $\mathrm{ZnO}-\mathrm{CuO}$}

Analisa FTIR digunakan untuk menganalisa gugus $\mathrm{ZnO}-\mathrm{CuO}$ pada partikel yang terbentuk. Gambar grafik hasil uji FTIR disajikan pada Gambar 2.

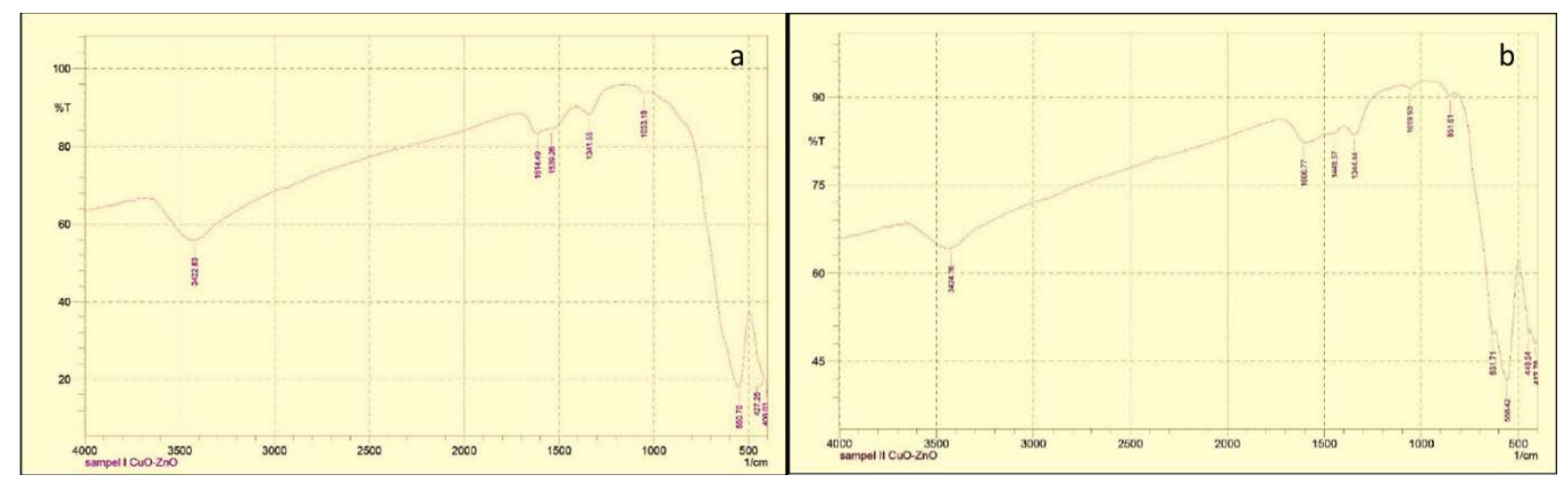

Gambar 2. Grafik analisis FTIR komposit $\mathrm{ZnO}-\mathrm{CuO}$ menggunakan asam asetat $0.15 \mathrm{M}$ (a) dan $0.3 \mathrm{~m}$ (b)

Terbentuknya gugus $\mathrm{ZnO}-\mathrm{CuO}$ pada partikel yang dihasilkan terlihat pada Gambar 2(a) dan (b). Ikatan $\mathrm{Cu}$ O terletak pada rentang bilangan gelombang $700-400 \mathrm{~cm}^{-1}$ [11]. Pada Gambar 2(a) dengan 0,15 M asam asetat terdapat puncak pada $550,70 \mathrm{~cm}^{-1}$ dan pada Gambar 2(b) dengan $0,3 \mathrm{M}$ asam asetat terdapat puncak pada $558,42 \mathrm{~cm}^{-1}$ yang menandakan terbentuknya ikatan $\mathrm{CuO}$ pada kedua sampel ini. Pada Gambar 2(a) dan (b) juga terbentuk ikatan $\mathrm{ZnO}$ ditandai dengan terbentuknya puncak pada 406,03 $\mathrm{cm}^{-1}$ dalam Gambar 2(a) dan $412,78 \mathrm{~cm}^{-1}$ pada Gambar 2(b).

Analisa XRD digunakan untuk menentukan ukuran komposit, banyaknya fasa yang terbentuk, dan bentuk struktur. Analisa XRD dilakukan pada $2 \theta$ rentang $25-75^{\circ}$, menggunakan radiasi $\mathrm{Cu}-\mathrm{k} \alpha$ dengan panjang gelombang 0,154 nm. Grafik hasil analisa XRD ditunjukkan pada Gambar 3. 


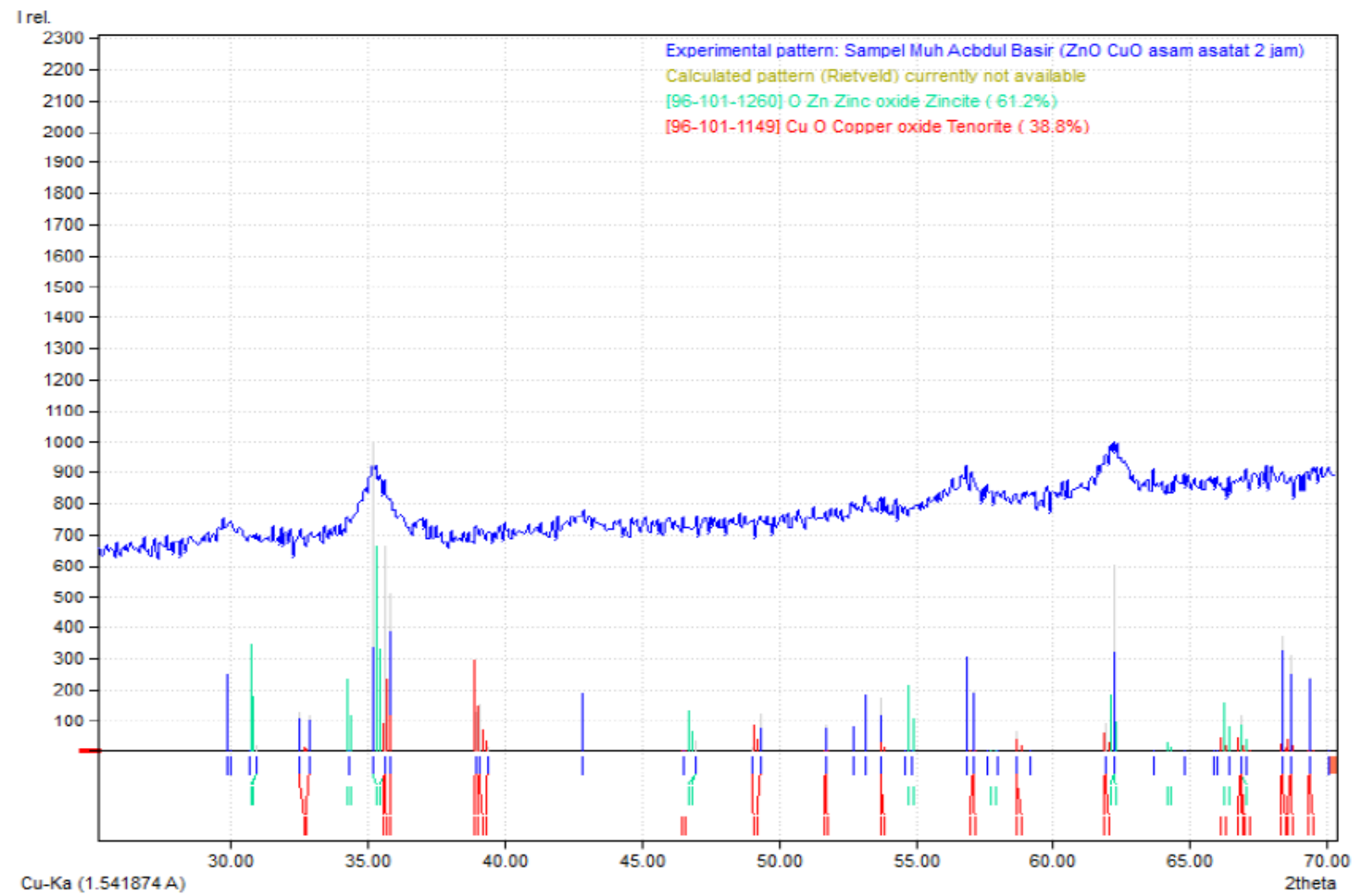

Gambar 3. Grafik analisis XRD komposit ZnO-CuO menggunakan asam asetat $0.15 \mathrm{M}$

Analisis Gambar 3. menunjukkan komposisi tiap sampel, dan titik puncak tertinggi. Hasil analisa menunjukkan bahwa komposisi fasa $\mathrm{ZnO}$ sebesar 61,2\% dan $\mathrm{CuO}$ sebesar 38,8\% dengan puncak tertinggi 35,22 20 . Data titik puncak tertinggi yang didapat, digunakan untuk mengetahui ukuran komposit yang dihasilkan dengan menggunakan persamaan Scherrer. Hasil perhitungan ukuran komposit menunjukkan bahwa puncak tertinggi 35,22 o2 $\theta$ dengan ukuran komposit 24,39 $\mathrm{nm}$. Berdasarkan hasil analisa XRD ZnO yang dihasilkan dari sampel asam asetat memilik struktur hexagonal yang sesuai dengan database COD (Crystallography Open Database) no. 96-101-1260 untuk sampel 1,5 M asam asetat. CuO yang didapat dari sampel asam asetat memiliki struktur monoclinic yang sesuai dengan database COD no. 96-101-1149.

Analisa XRF digunakan untuk menganalisa komposisi kimia beserta konsentrasi unsur-unsur yang terkandung dalam suatu sampel. Gambar grafik hasil uji XRF disajikan pada Gambar 4.
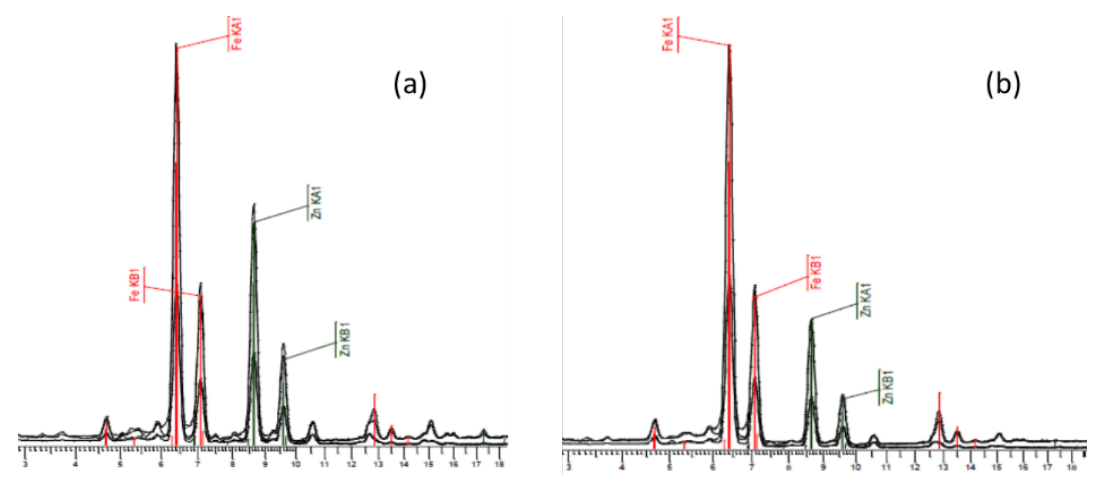

Gambar 4. Grafik analisis XRF komposit ZnO-CuO menggunakan asam asetat $0.15 \mathrm{M}$ (a) dan $0.3 \mathrm{~m}$ (b)

Berdasarkan hasil analisa XRF yang telah dilakukan dapat disimpulkan bahwa pada sampel larutan sintesis 0,15 $\mathrm{M}$ asam asetat mengandung konsentrasi $\mathrm{ZnO}$ sebesar 25,54\% dan CuO sebesar 0,09\% dan pada sampel 
larutan sintesis $0,3 \mathrm{M}$ asam asetat mengandung konsentrasi $\mathrm{ZnO}$ sebesar 9,94\% dan $\mathrm{CuO}$ sebesar $0,02 \%$. Penggunaan konsentrasi asam asetat mempengaruhi komposisi komposit karena kekuatan asam asetat untuk membantu oksidasi logam $\mathrm{Cu}$ dan $\mathrm{Zn}$ menjadi berbeda. Konsentrasi asam yang tinggi menyebabkan migrasi elektron menjadi lebih cepat sehingga oksidasi dapat berlangsung dengan cepat. Oksidasi yang logam yang tidak terlalu kuat akan menyebabkan jumlah $\mathrm{Cu}$ dan $\mathrm{Zn}$ yang teroksidasi menjadi sedikit. Tetapi jika konsentrasi asam yang terlalu tinggi, $\mathrm{CuO}$ dan $\mathrm{ZnO}$ menjadi lebih sulit terendapkan.

\subsection{Efektivitas Komposit ZnO-CuO sebagai Katalis Fotodegdrasi Methyl Orange}

Mekanisme reaksi fotokatalitik melalui beberapa tahap yaitu: absorbsi sinar oleh semikonduktor sehingga menyebabkan pembentukan dan pemisahan $(\mathrm{e}-)$ dan $(\mathrm{h}+)$, absorbsi reaktan, reaksi redoks, dan desorbsi polutan. Metode fotodegradasi merupakan metode relatif murah dan mudah diterapkan dan dapat menguraikan zat warna menjadi komponen-komponen lebih sederhana yang lebih aman bagi lingkungan.

Reaksi yang terjadi pada pengaktifan $\mathrm{ZnO}-\mathrm{CuO}$ dengan adanya sinar [2].

$\mathrm{ZnO}-\mathrm{CuO}$ yang disuspensikan dalam air apabila diiradiasi dengan sinar UV akan membentuk Reactive Oxygen Spesies (ROS) atau molekul oksigen reaktif yang akan mendegradasi zat warna metil orange menjadi intermediet yang lebih sederhana yang kurang atau tidak beracun. Mineralisasi sempurna metil orange akan menghasilkan $\mathrm{CO}_{2}$ dan $\mathrm{H}_{2} \mathrm{O}$. OH・ yang terbentuk merupakan oksidator utama yang sangat kuat, nonselektif, dan destruktif. Efektivitas yang telah didapatkan dalam percobaan ini, disajikan pada Gambar 5.

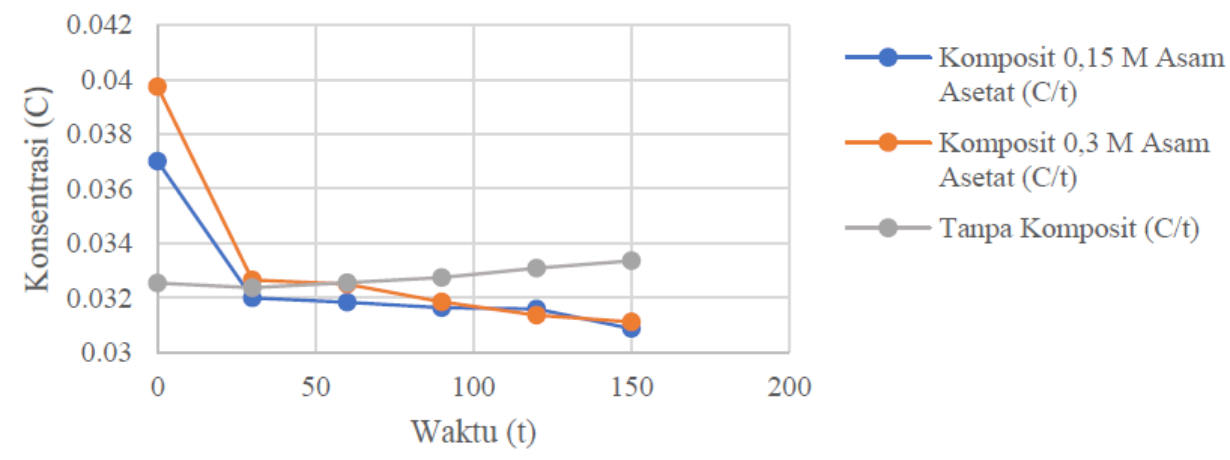

Gambar 5. Grafik kurva efektivitas katalis komposit $\mathrm{ZnO}-\mathrm{CuO}$ dengan 0,15 M dan 0,3 M Asam Asetat

Hasil perhitungan yang telah dilakukan diperoleh bahwa sampel larutan metbyl orange dengan komposit 0,15 $\mathrm{M}$ asam asetat memiliki efektivitas sebesar 16,58\%. Sedangkan sampel larutan metbyl orange dengan komposit $0,3 \mathrm{M}$ asam asetat memiliki efektivitas sebesar $21,69 \%$. Sebagai pembanding, dilakukan pengukuran sampel larutan methyl orange tanpa komposit memiliki efektivitas sebesar -2,5\%.

Komposisi komposit dengan asam asetat $0.15 \mathrm{M}$ mempunyai presentase yang lebih $\mathrm{Cu}$ dan $\mathrm{Zn}$ yang lebih tinggi daripada komposit dengan asam asetat $0.3 \mathrm{M}$. Komposisi $\mathrm{Cu}$ dan $\mathrm{Zn}$ yang lebih besar ternyata tidak selalu memberikan efektivitas yang lebih baik. Hal ini kemungkinan disebabkan oleh distribusi dan posisi $\mathrm{Cu}$ dan Zn dalam partikel. Komposisi yang besar tetapi berada di dalam partikel dan tidak terdistribusi sempurna menyebabkan penurunan efektivitas katalis. Hepotesis ini tentu membutuhkan penelitian yang lebih lanjut.

\section{Kesimpulan}

Katalis komposit $\mathrm{ZnO}-\mathrm{CuO}$ telah berhasil disintesis secara elektrokimia. Uji efektivitas katalis yang dihasilkan dari komposit dengan konsentrasi 0,3 $\mathrm{M}$ asam asetat sebesar 21,69\% lebih optimal dibandingkan efektifitas yang dihasilkan dari komposit dengan konsentrasi $0,15 \mathrm{M}$ asam asetat sebesar 16,58\%.

Komposit $\mathrm{ZnO}-\mathrm{CuO}$ Hasil Sintesis dengan Metode Elektrokimia sebagai Katalis 


\section{References}

[1] Abdullohi, Y., Abdullah, A.H., Zainal, Z., and Yuzof, N.A., 2011,"Photodegradation of m-cresol by Zinc Oxide Under Visible-light Irradiation", International Journal of Chemistry, 3, 3

[2] Kasuma, N.Y., 2012, "Penggunaan Komposit $\mathrm{ZnO}-\mathrm{CuO}$ yang disintesis secara Sonochemistry yang digunakan sebagai Katalis untuk Fotodegradasi Metil Orange dan Zat Antibakteri", hal. 8-9, Universitas Andalas, Padang

[3] Tjatur, R., 2003, "Solar Cell Energi Masa Depan yang Ramah Lingkungan”, Energi.lipi.go.id

[4] Zuo, Z.J., Wang, L., Liu, Y.J., and Huang, W., 2013, "The effect of $\mathrm{CuO}-\mathrm{ZnO}-\mathrm{Al}_{2} \mathrm{O}_{3}$ catalyst structure on the ethanol synthesis from syngas", Catalysis Communication 34, 67-72

[5] Lei, H., Hou, Z., and Xie, J., 2016, "Hydrogenation of $\mathrm{CO}_{2}$ to $\mathrm{CH}_{3} \mathrm{OH}$ over $\mathrm{CuO} / \mathrm{ZnO} / \mathrm{Al}_{2} \mathrm{O}_{3}$ catalysts prepared via a solvent-free routine", Fuel, 164, 191-198

[6] Widiarti, N., Sae, J.K., and Wahyuni, S., 2017, "Synthesis CuO-ZnO nanocomposite and its application as an antibacterial agent", IOP Conf. Series: Materials Science and Engineering, 172, 012036

[7] Simsikova, M., Cechal, J., Zorkovska, A., Antalik, M., and Sikola, T., 2014, "Preparation of CuO/ZnO nanocomposite and its application as a cysteine / homocysteine colorimetric and fluorescence detector", Colloids and Surfaces B: Biointerfaces, 123, 951-958

[8] Abraham, N., Rufus, A., Unni, C., and Philip, D., 2018, "Dye sensitized solar cells using catalytically active $\mathrm{CuO}-\mathrm{ZnO}$ nanocomposite synthesized by single step method", Spectrochimica Acta Part A: Molecular and Biomolecular Spectroscopy 200,116-126

[9] Takeno, N., 2005, "Atlas of Eh-pH Diagrams", hal. 86-287, National Institute of Advanced Industrial Science and Technology, Japan

[10] Das, S., dan Vimal, C.S., 2017, "Synthesis and Characterization of $\mathrm{ZnO} / \mathrm{CuO}$ Nanocomposite by Electrochemical Method", ISSN: 1369-8001, hal 173-177

[11] Johan, M.R., 2011, "Annealing Effect on the Properties of Copper Oxide Thin Films Prepared by Chemical Deposition Int”, Journal Electrochem, 6, 6094-6104 